\title{
The concept and activity of 'obedience' in the Gospel of John
}

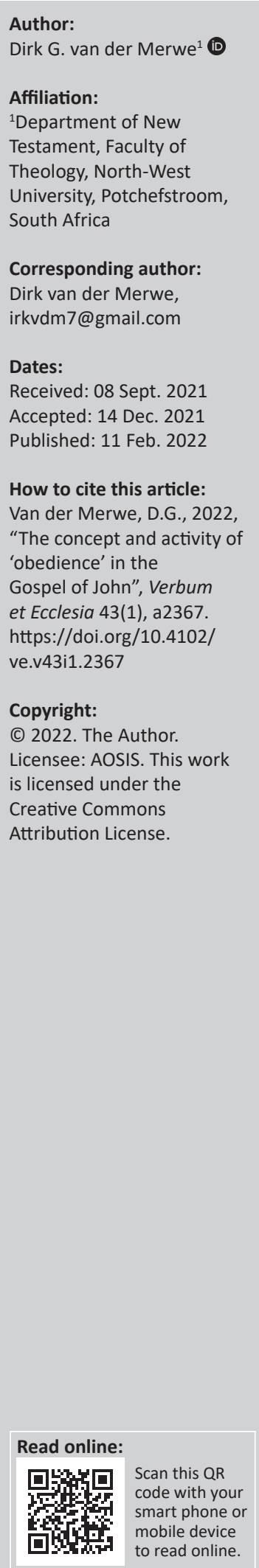

The concept and activity of obedience can be regarded as fundamental to human existence as well as to Christian religion. The focus of this study was to investigate the occurrence of this concept in the Gospel of John. Of the two well-known Greek nouns vi $\pi \alpha \kappa o \eta$ and $\dot{\alpha} \pi \varepsilon 1 \theta \varepsilon \dot{\varepsilon} \omega$ (translated as 'obedience'), and the two related verbs 'obedient'), only $\alpha \dot{\alpha} \varepsilon 1 \theta \dot{\varepsilon} \omega$ occurs once (3:36) in the Gospel of John. The verb $\tau \eta \rho \varepsilon ́ \omega$ has been used several times and not consistently translated because of diverse literary contexts. The objective of this study was to point out how the Gospel of John is filled with the obedience concept and how it was implied from different perspectives. The following themes associated with obedience will be discussed: (1) obedience to God as Father, (2) the essence of obedience - to love, (3) various expressions of obedience, (4) the ability to obey, (5) Christian obedience is to become like Jesus and (6) the rewards of being obedient.

Intradisciplinary and/or interdisciplinary implications: The concept and activity, 'obedience', are understood as a virtue fundamental to human existence, as well as fundamentally essential and important for the Christian religion. This article investigates the occurrence of 'obedience' in the Gospel of John. To experience God's blessings and enjoy God's communion, God should be obeyed.

Keywords: obedience; Gospel of John; concept; activity; human existence.

\section{Introduction}

This study approaches the concept of obedience as a person's will to comply with an instruction, invitation, proposal or laws of authority and custom. Secular and religious societies across many cultures and eras seem to accept that obedience is an indispensable custom: a custom to be respected and observed in our homes, workplaces and communities to which we belong. This is evident from everyday life, where obedience emerges as a lifelong norm to be respected and to be adhered to by all people. Hence, in terms of concept and activity, obedience is understood as a virtue fundamental to human existence, as well as fundamentally essential and important for the Christian religion.

There are very little academic publications on the explicit use and featuring of the noun, 'obedience' and the verb 'obedient', in the Bible. ${ }^{1}$ Likewise, no formal academic publications have been found on the concept of obedience in the Gospel of John. This is probably because of the omission of the noun (obedience) and the verb (obedient) in the Greek text. According to the semantic dictionary of Louw and Nida (1996:467-470), there are 18 semantic-related variants to the term

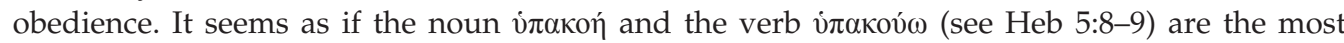
familiar literary vocabulary for the translation of obedience, but do not occur in the Gospel of

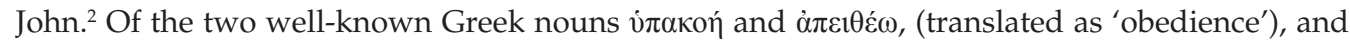
the two related verbs $\dot{\pi} \alpha \kappa o v ́ \omega$ and $\dot{\alpha} \pi \varepsilon 1 \theta \dot{\varepsilon} \omega$, (translated as 'obedient'), $\dot{\alpha} \pi \varepsilon 1 \theta \dot{\varepsilon} \omega$ occurs only once (3:36) in the Gospel of John. The most frequently used verb for obedience in the Gospel of John is $\tau \eta \rho \varepsilon ́ \omega$, although sometimes differently translated because of the literary context. ${ }^{3}$ Even though the

1. According to my survey, it seems as if not much has been academically published on obedience, neither in the Old Testament nor in the New Testament. During 2001, Bill Berends published in Vox Reformata an article titled, 'The Obedience of Jesus Christ. A Defense of the doctrine of Christ's Active Obedience'. Not a single source, regarding obedience, has been consulted. Some years later, the following articles were followed: Das (2009:795-812); Kelly (2013:1-24); Taylor (2017:343-359, 2018:51-69).

2. Arndt, Danker and Bauer (2000:1028) translate these two words as: the noun úrakon' as 'a state of being in compliance, obedience'

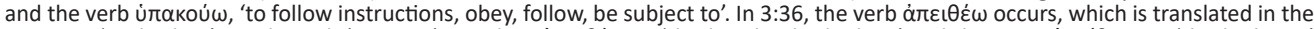
NRSV as, 'to disobey'. Arndt et al. (2000:99) translate $\dot{\alpha} \pi \varepsilon(\theta \varepsilon \dot{\varepsilon} \omega$ as 'disobey, be disobedient' and the noun $\dot{\alpha} \pi \varepsilon i \theta \varepsilon เ \alpha$ as 'disobedience' (see Heb 4:6).

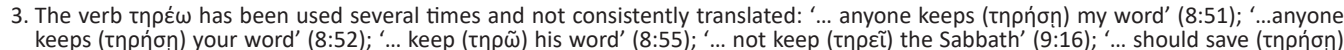

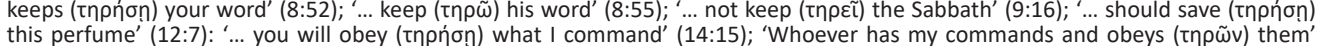

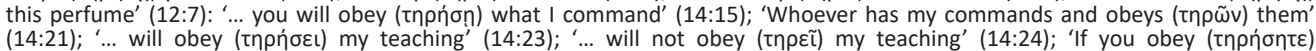

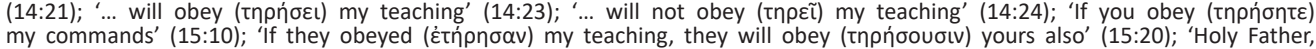
protect (tŕp 


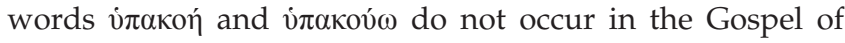
John, still the concept of 'obedience' is present or implied in discipleship, living a life of holiness, living according to God's will, ethics, ${ }^{4}$ mimesis $^{5}$ and the like.

Obedience implies the existence of a relationship. In the Gospel of John, believers learn through the example (i்ó $\delta \varepsilon \imath \gamma \mu \alpha, 13: 15)$ of Jesus that they are called to a relationship with Jesus and consequently a life of obedience. Anyone who wants to know God - who wants to walk closely with God - must obey God. This seems to be a strong declaration. Unfortunately, no other way exists to draw believers into a close relationship with God, experience entirely God's blessings and enjoy the communion that believers desire, without obeying God.

The objective of this study was pointing out how the Gospel of John is filled with the concept of obedience, even though the noun and verb do not explicitly occur. The following themes associated with obedience will be discussed: (1) obedience to God as Father, (2) the essence of obedience - to love, (3) various expressions of obedience, (4) the ability to obey, (5) Christian obedience is to become like Jesus and (6) the rewards of being obedient.

\section{Obedience to God as father}

Obedience should always have an object. According to the Gospel of John, both God and Jesus are referred to as objects of obedience. Jesus legitimises his obedience in his references to God as Father. The Johannine use of the noun father ( $\pi \alpha \tau \eta \rho)$ is not distinctive to the teaching of Jesus or is not even innovative of the author in his references to the relation between Jesus and God. According to D'Angelo (1999:59), it seems to be rather 'the theological understanding and product of communal reflection, cultural meaning, and authorial creativity'.

According to Meyer (1996:264), a Sendertheologie occurs in the Gospel of John and not so much a Gesandtenchristologie. ${ }^{6}$ This surely provides a decipherment of 'father' in the Gospel of John. The noun Father can be regarded as a title of God, 'a title in apposition to "God" or "Lord" in the texts of early Christianity' (D'Angelo 1999:59). The Gospel of John uses the two nouns $\pi \alpha \tau \eta \dot{\rho}$ (father) and $\theta \varepsilon$ ć $\varsigma$ (God) interchangeably in the same contexts: direct discourses and speeches of Jesus. Thompson (2001:57) refers to this usage as substitution. ${ }^{7}$ (footnote 3 continues...)
list of semantic-related vocabulary for obedience in the study by Louw and Nida
$(1996: 467-470)$

4.On ethics, see the study by Brown and Skinner (eds. 2017), and Van der Watt and Zimmermann (eds. 2012).

5.See the study by Bennema (2018) for his discussions on 'the believer-Jesus mimesis, the believer-God mimesis, the paradigmatic Son-Father mimesis, and a latent SpiritJesus mimesis'.

6.See: 'do the will of Him who sent me' $(4: 34 ; 5: 30 ; 6: 38 ; 8: 29)$ to be discussed in the section 'Following the will of God $(4: 34 ; 5 ; 30 ; 6: 38 ; 8: 29)$ '.

- 'My food is to do the will of him who sent me and to complete his work' (4:34);

- 'I seek to do not my own will but the will of him who sent me' $(5: 30)$;

- '... not to do my own will, but the will of him who sent me' (6:38);

- 'And the one who sent me is with me; ... I always do what is pleasing to him' (8:29);

- In these texts, it is clear that Jesus'; references to 'him (the one) who sent me' and 'the Father who sent me' (14:24) refer to God's name (cf. Meyer 1996:264).

7.See the study by Thompson (2001:69-80) for an excellent discussion on 'God as Father in the Gospel of John'
The title 'father' calls familial imagery into play. The unique usage of 'father' in the Gospel of John was established upon the distinctive and revelatory practice of Jesus (cf. 1:18). This kind of usage effected some consequences in the picturing of Jesus and his followers to whom he preached. For Jesus, the inference of 'Father' was to proclaim the reign and authority of God (cf. D'Angelo 1999:77). Jesus calls God 'the Father' or 'my Father' throughout his public ministry. It is only at the end of the Gospel (20:17) that God is identified as the Father of believers. For many readers, 'Father' is a familiar and meaningful way to refer to God (cf. Thompson 2001:57). Jesus' reference to God in this manner was to identify God in relational terms. Believers come to know God as Father by examining how God and Jesus, his Son, interact with each other as a model how God relates to his children (cf. Thompson 2001:71).

According to Koester (2008:47, 48), the following are three major qualities of the identity of God as Father in the Gospel of John : '[h]e is a source of life, one who loves his children, and someone worthy of honour and obedience' ${ }^{8}$ Firstly, God the Father is the source of life for Jesus, his Son. Therefore, Jesus could say, 'just as the Father has life in himself, so he has granted the Son also to have life in himself' (5:26). Life is a quality of God (Koester 2008:48). Secondly, the relationship of the Father with the Son revolves around his love for the Son. God's love unites the Father with the Son and is extended by the Son to others. Although references to love customarily communicate a sense of intimacy and emotion or feeling, in the Gospel of John, love is primarily understood as a bond of commitment. It is this bond of commitment that will empower Jesus to accomplish the will of his Father. The love of the Father becomes evident by providing the Son responsibilities as well as power to accomplish them (3:35; 5:20; Koester 2008:49). Thirdly, the Father-Son relationship also involves honour and obedience. Honour comprises the value and respect of one another. Obedience can be an expression of honour, meaning that the person does what the father asks. In the fourth Gospel, the obedience of the Son to the Father is grounded in 'the love and honour that constitute the relationship' (Koester 2008:50).

God is also referred to as the Father of believers after Jesus' death and resurrection. At the empty tomb, Jesus says to Mary Magdalene, ' $\mathrm{g}] \mathrm{o}$ to my brothers and say to them, "I am ascending to my Father and your Father, to my God and your God"' (20:17). The perception is that through their relationship with Jesus, people will know God as their Father. This then implies, firstly, that 'God the Father is the source of life for believers' (Koester 2008:51). Already in the prologue, a declaration occurs about people becoming children of God (1:12) and born of God (1:13). Then, in John 3, the people are said to be born of water and Spirit (3:5) or from above (3:7). To be born from God implies to have faith in the Son (5:24; Koester 2008:51). Secondly, the Father also relates and extended his love to the world through his Son (3:16). When people love Jesus, they also love the Father who sent him. Thirdly, the relationships between believers and the Father should also be characterised by honour and obedience. 8.If God is like a human father in some ways, $\mathrm{He}$ is different from a human father (Koester 2008:48) 
As the Father instructed Jesus about what to say and what to do, similarly Jesus obediently communicated this to his followers: they should love one another (13:34). To love Jesus is expressed in keeping his commandment. Obedience to this will lead to experiencing the love of the Father (14:21). Through their obedience to Jesus, they will glorify the Father and make known the Father's love (15:8-10; Koester 2008:52). ${ }^{9}$

\section{The essence of obedience - To love (Jn 15:9)}

The Father is bound to the Son via love, which is consequently extended to others via the Son. In general, love conveys a consciousness of intimacy and feeling. However, in the Gospel of John, love is primarily understood as a bond of commitment. A mutuality of love exists between the Father and the Son; if the Father loves the Son then the reverse is also true: the Son will also love the Father $(5: 35 ; 14: 31)$. This enables Jesus to fulfil the will of the Father. Additionally, the character of God is evident in that He loves the world unfortunately, in this instance, the love is not mutual. This proves that the love of God exceeds to be a feeling. Because of his commitment to the world, God has sent the Son, whom he loves, to communicate his own love to a world, alienated from its Creator (Koester 2008:49). The love in the Christian community will serve as a witness to the world, so that the world may 'believe' (17:21) and 'know' (17:23) that the Father has sent the Son.

Here, it is necessary to realise that although the Father's love and the love of believers can be distinguished, they are not to be separated. Both engage the Son: 'the Father himself loves you, because you have loved me and have believed that I came from God' (16:27). From this statement of Jesus, it is clear that love constitutes a bond in which believers live.

Love from the Father is fundamental for God's children because they are requested to share their love with others. The Father's love for the Son was not limited to the Son. The Son incarnated to extend the Father's love through the ministry and crucifixion of Jesus. After communicating to his followers, the Father's love, Jesus called them to love one another. To express love within any community is not so easy. Even though faith creates relationships, still human weaknesses and deficiencies continue to be part of the believer's daily life - this is evident in the Gospel from the human side of Jesus' disciples. After challenging his disciples to love one another, Jesus assures those loving him and keeping his word that 'the Father will love them' and then both, he and the Father will come to them and reside in them (14:23; Koester 2008:52).

\section{Expressions of obedience in John}

In the Gospel of John, there are three basic phrases referring explicitly to obedience: 'doing the will of God', 'finishing the work the Father gave...' and 'obey ( $\tau \eta \varepsilon \dot{\varepsilon} \omega)$ my commands'. ${ }^{10}$

9.See the study by Thompson $(2001: 57-58,69-80)$ for a more thorough discussion of God as Father in the Gospel of John.

10.Although the act of 'obedience' is implied in discipleship, living a life of holiness, ethics, mimesis and the like, it will not be discussed in this essay because of space constrain.

\section{Doing the will of God $(4: 34 ; 5 ; 30 ; 6: 38 ; 8: 29)$}

The assertion is that the obedience of an agent 'to do the will of the sender' is a legitimate hypothesis. ${ }^{11}$ It is part of the main configuration of any one being sent to do the will of the sender. An agent will not speak or act in his own name but epitomises the sender (Haenchen 1984:30). This principle is clear in Christ's life: as the obedient agent, he did what was commanded by the Father (Borgen 1968:140).

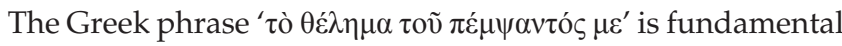
in the study of obedience in the Gospel of John (cf. Lindars 1981:194) and occurs in 4:34, 5:30 and 6:38. In 8:29, тò $\theta \dot{\lambda} \lambda \eta \mu \alpha$ is replaced by ' $\tau \grave{\alpha} \alpha \dot{\alpha} \rho \varepsilon \sigma \tau \grave{\alpha} \alpha \nu ่ \tau \tilde{\omega} \pi 01 \tilde{\omega}$ ', although the objective remained unchanged (see Box 1).

The entire life of Jesus is focussed on completing the will of

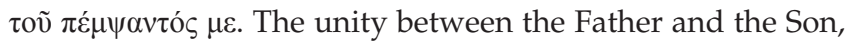

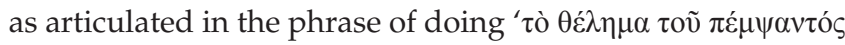
$\mu \varepsilon^{\prime}$ (6:38), refers to an operative and honourable unity (cf. Lindars 1981:194). Honourably, it comprises Jesus' voluntaryintentional and complete obedience to the will of the Father. This unity then validates Jesus' exclusive claim for the faithfulness of people (cf. 3:16-21, 31-36). His obedience towards the Father governed his entire life to culminate in the Cross (cf. Van der Merwe 1995:316).

In conclusion, these references of Jesus elucidate various perspectives regarding his obedience to the will of the Father and his mission (see Box 1):
4:34 .... desire
$5: 30$.... dependence
$6: 38$.... purpose (salvation of man)
$8: 29$.... presence of the Father and obedience of Jesus. ${ }^{12}$

These references regarding the submission of Jesus to the will of the Father aught not be interpreted to reduce Jesus' identity to be that of a conventional agent of the Father. Jesus expresses distinctly the inattentiveness about his own will $(5: 30 ; 6: 38)$. His intention is only following 'the will of him who sent me'. Jesus, as the Son of God, is in an exclusive way an agent. His mission is not founded in an ordinary historical commissioning, but in something much deeper. 'Throughout his mission he experiences the presence of his Father in him which enables him to fulfil the will of the Father in obedience' (cf. Van der Merwe 1995:321-322).

BOX 1: Explicit references of Jesus' doing the will of the 'One who sent me'.

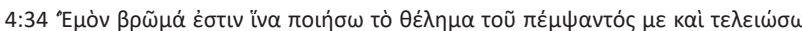

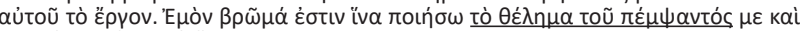

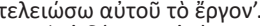

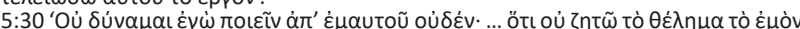

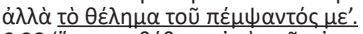

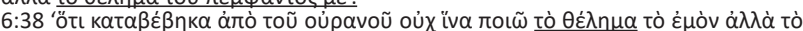

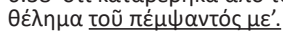

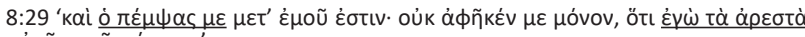

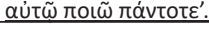

11.This assertion is verified in the following halakhic sources: Erubin $31 \mathrm{~b}-32 \mathrm{a}$ Qiddushin 2:4 and Terumoth 4:4 as quoted by Borgen (1968:140).

12.See also 7:18 and 8:50. 


\section{Jesus finishes the work that the Father gave him to do $(14: 31 ; 17: 4)$}

This subsection refers to the foundation and culmination of obedience in John, namely, love (14:31) and glory (17:4) (see Box 3). Jesus' obedience to the Father revolves around these two fundamental activities. The Gospel of John legitimates the Son's obedience to the Father in the love and honour that constitute their relationship (Keener 2003:50).

\section{Jesus' obedience is rooted in his love for the Father (14:31)}

In 14:31, Jesus communicates to his disciples that 'the world may know that I love the Father, and just as the Father

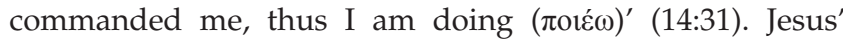

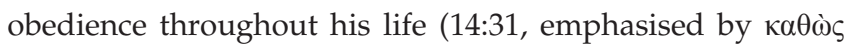
and ovi $\omega \varsigma$; cf. 8:29 and 17:4) is admirable, ${ }^{13}$ while his opponents undermined obedience to God (Keener 2003:987).

The crucifixion of Jesus is the culmination of Jesus' love for the Father. He had this in mind when he prayed that he finishes 'the work that you gave me to do' (17:4). Just as the Son, himself, persevere in the love of his Father by keeping his commandments $(8: 29 ; 15: 10)$ analogous should be the love of the disciples of Jesus be attested by their obedience to their Master (14:15, 21, 23; also 10:17-18; Carson 1991:509).

\section{Jesus finishes the work that the Father gave him to do to glorify Him (17:4)}

In his gospel, John clearly guides the readers towards Jesus' obedience to the Father. In 4:34, the author refers to the work that the Father gave Jesus to complete. In 5:36, he uses the plural, 'works', to substantiate the diversity of these works. Then in 17:4, Jesus expresses that through his obedience (17:6-8), he has completed the work that is related to $17: 1$, which reflects that he has glorified the Father. He then completed his last work by yielding his life to God through his crucifixion (19:30, 'It is finished' Beasley-Murray 1999:297). When Jesus speaks about glorifying God in completing or fulfilling his assigned work, he anticipated the cross (see 17:1-4; Borchert 2002:191).

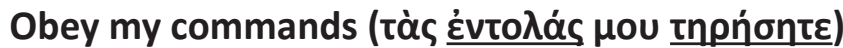

The phrase 'obey my commands' (15:10) is equivalent to 'doing the will of God' (see Box 2):

BOX 2: The equivalence between 'obey my commands' and 'doing the will of God'.

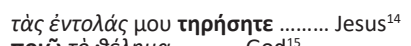
$\pi$ oเ $\tilde{\omega} \tau \dot{\omega} \vartheta \dot{\varepsilon} \lambda \eta \mu \alpha \ldots \ldots \ldots . .$. God $^{15}$

Although different vocabularies have been used, the abovementioned phrases construct a chiasm, indicating that the two nouns $\dot{\varepsilon} v \tau o \lambda \alpha \dot{\zeta}$ and $\theta \varepsilon \dot{\lambda} \lambda \mu \alpha$ relate to one another, as well as the

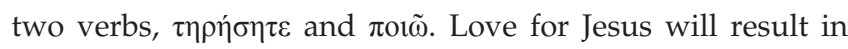
keeping the commands of Jesus. The interchange of 'my 13.Cf. Moses, who did 'as he was charged to do beforehand' (Josephus [1987] Ant. 2.349) 14.John 12:49f; 13:34; 14:15, 21, 31; 15:10, 12, 14, 17.

15.John $4: 34 ; 5: 30 ; 6: 38 ; 8: 29$. commands' with 'my word' and 'my words' in 14:21, 23, 24 implies that these references encompass, not some merely ethical instructions, but the complete choice of the revelation from the Father (cf. 8:31-32; 12:47-49; 17:6). Those who love Jesus will live in the light and truth (Beasley-Murray 1999:256).

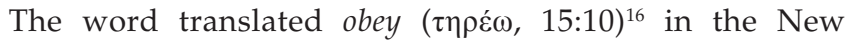
English Version (NIV) literally means 'to keep/to observe' as translated in the New Revised Standard Version (NRSV). According to the literary context, the meaning 'to obey' seems obvious. It is also equivalent to the phrase used in Matthew 19:17 for obedience to the 10 Commandments. In John 14:15,21, Jesus refers to the obeying of commandments, ${ }^{17}$ while in verses 14:23, 24 (so also 8:51 and 15:20), Jesus refers to the obedience of his teaching (literally 'word' or 'words'; Newman \& Nida 1993:465). ${ }^{18}$ Then in John 14:18-21, Jesus promises his disciples that he will return and will be with them if they are obedient to him (Newman \& Nida 1993:464).

\section{The ability to be obedient according to John}

This section deals with the following four aspects in order to get a broad perspective of how the author tries to influence the reader to act in obedience: (1) to follow Jesus, (2) to abide in Jesus, (3) their deeds have been done in the name of God; (4) the Paraclete will guide the disciples in all truth.

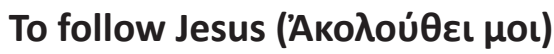

The Gospel of John, as a narrative, is filled with horizontal and vertical dualisms, to call for a radical change of life to be faithful followers of Jesus. In fact, the Gospel decisively invites readers 'into a profound spiritual experience of God and divine realities in and through Jesus' (Kim 2017:5). A life of 'following Jesus' ${ }^{19}$ comprises a life sincerely engaged in the 'heavenly' realities. The journey of 'following Jesus' comprises a journey of experiencing God, being obedient in keeping his words, washing one another's feet and abiding in the continuing of Jesus' mission. This enables Jesus' followers to participate in the Father-Son communion (Kim 2017:5).

BOX 3: 'Glorification' the consequence of 'obedience'.

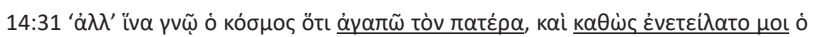

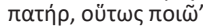

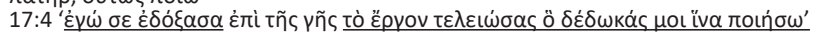

16.See footnote 2 and cf. 1 John $2: 3,4 ; 3: 22,24 ; 5: 3$.

17.In this context of the Gospel of John, the use of 'commandments', 'word' and words' have the same meaning. The equivalence of 'word' and 'commandment' originates from the Old Testament. There the Decalogue is referred to as 'the words' of God (cf. Dt 5:5). In 14:21, 23, 24, the references to the 'commandments' the 'words' and the 'word' of Jesus are all references to the love command (Newman \& Nida 1993:465).

18.This verb has been used to express obedience with regard to keep my (8:51), your $(8: 52)$, his $(8: 55)$ word; to obey commands $(14: 15,21 ; 15: 10)$ and to obey the teaching of Jesus $(14: 23,24 ; 15: 20)$.

19.Cf. the study by Kim (2017), for a thorough discussion of what John communicates in all his references 'to follow Jesus'. 


\section{To abide in Jesus}

The 'abiding' motif ${ }^{20}$ is distinctive in the Gospel of John. It occurs in seven verses in John $15 .{ }^{21}$ Jesus urges his disciples to remain faithful to him after his ascension. The theme of abiding is spelled out in chapter 15 and 1 John. To 'abide' is like 'to be'. To abide in Christ is to be in Christ. But 'to abide' is more. It adds a dimension to fellowship' (Peterson 2013:15, 16). To abide in him is to follow him as the fundamental source 'of help and strength, to bear much fruit' (Ridderbos

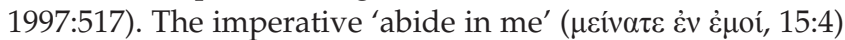
emphasises that 'apart from me you can do nothing' (15:5). This reference to 'nothing' relates to the new commandment given by Jesus, because of the life given by him (Ridderbos 1997:517). What is meant by abiding in Christ is explained in 15:7 and 9 (Hendriksen \& Kistemaker 2001:299): to abide in his words (15:7) and to abide in his love (15:9).

'Abiding' then means to continue having fellowship with him, to love him, keeping his commands even as he kept the commands of the Father (15:10). Beasley-Murray (1999:272) correctly stated: Abiding:

[C]onnotes continuing to live in association or in union with him ... To 'remain' in Jesus is also to remain in his love, just as Jesus throughout this life remained in the Father's love. (cf. also Peterson 2013:24)

The call of Jesus to his disciples to 'abide in him' and to 'abide in his love' is a call for obedience. The loving relationship depicted here refers to a relationship of dependence on Jesus. Such a relationship is focussed on Jesus and seeks to dwell in his words (cf. Stander 2016:20).

\section{Their deeds have been done in the name of God (3:21)}

In John 3:21, the author makes a strange expression, 'But he who does the truth comes to the light, that his deeds may be clearly seen, that they have been done in God' (NKJV). In the biblical environment, 'truth' is not an abstract idea. When a declaration is made that God is true, it means basically that God is faithful. Correspondingly, when the author refers to people following the truth, 'he refers to those who continue in faithful obedience to God' (Newman \& Nida 1993:93). Within the context of this verse, it refers to the faithful response of believers to the revelation of light that God has communicated regarding Godself (Newman \& Nida 1993:93). This strange expression makes it clear that every performance

20.According to Brodie (1993:476), the context is provided by the preceding chapter and by its emphasis on the idea of an abode (cf. 14:2,23); this prepares the way for the repeated emphasis which 15:1-17 places on the idea of abiding. The essence the repeated emphasis which 15:1-17 places on the idea of abiding. The essence
of the abode/abide language is the concept of union: chap. 14 establishes it, and of the abode/abide language is the concept of union: chap. 14 establishes it, and
$15: 1-17$ develops it. Associated with abiding union is obedience of 'the word': a pattern repeated in 14:12-24 ('my commandments ... my commandments ... my word ... my words , ... the word 14:15, 21, 23-24) prepares for what follows ("the word ... my words ... my commandments ... my Father's commandments ... command you ... I command you", 15:3, 7, 10, 14, 17)'.

21.(1) 'Abide in me, and I in you' (v. 4); (2) 'As the branch cannot bear fruit by itself,

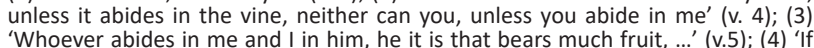
anyone does not in anyone does not abide in me.... (v. 6); (5) 'If you abide in me, and my words abide in you, ask whatever you wish, and it will be done for you' (v. 7); (6) 'As the Fathe has loved me, so have I loved you. Abide in my love' (v. 9); (7) 'If you keep my commandments, you will abide in my love, just as I have kept my Father's commandments and abide in his love (v. 10); (8) You did not choose me, but chose you and appointed you that you should go and bear fruit and that your fruit should abide' (v. 16). is done 'through God' - 'in union with Him, and therefore by His power' (Carson 1991:208; Westcott 1908:1.124). In the Gospel of John, the fundamental 'work' conceding the new eternal life is faith (6:27-30). However, Jesus also regarded obedience to God's will and mission $(4: 34,38 ; 17: 4)$ as part of God's work. Here, the author expands the notion that the deed of a person reflects who one is. ${ }^{22}$

Once when a person starts to live truly in the light that person will continue to keep God's other commandments (14:15, 23-24), the principal commandment, loving other fellow disciples (13:34-35), comes into picture.

One does the works of the one whose nature one shares (8:39, 41), hence birth from God's Spirit remains necessary for genuinely good works (3:6). ${ }^{23}$ Thus, for John, the emphasis on works does not allow salvation outside of obedient faith in Christ (Keener 2003:574).

\section{The Paraclete - 'He will guide you into all truth'}

In John 16:13, it is written that 'when He, the Spirit of truth, has come, He will guide you into all truth; for He will not speak on His own authority, but whatever He hears He will speak' (also 14:26). This text communicates that the Spirit is also obedient and communicates what the Spirit heard to communicate. The Spirit makes Jesus and the Father experiential and known (cf. Koester 2008:147, 149, 150). In 14:17, Jesus promises his disciples that the Paraclete will come and dwell with them, and in fact, will be in them (cf. Koester 2008:151).

Tenney (1981) makes a valuable statement on the meaning of

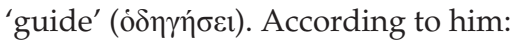

'[G]uide' implies leadership towards a person who is interested in travelling on the right path, but who needs help in finding it ... The believer may not have progressed far along the way of truth but is desirous of going on in the right direction and needs the good offices of the Spirit to take him on his way. (p. 235)

Köstenberger (1998:91) complements Tenney's statement in pointing out to Jesus' total dependency on the Father to be obedient to the will of God $(4: 34 ; 5: 30 ; 6: 38 ; 8: 29)$. This certainly has implications for the obedience of believers to the commandments of Jesus. Believers are dependent on the Spirit to follow Jesus and being obedient to his commandments.

\section{Christian obedience is to become like Jesus}

In the Gospel of John, the following three words have been distinguished to reflect on how a person can become like Jesus:

22. For the ethical implications of the Johannine community, see Rensberger (1988:59-61).

23.In the Gospel of John, the character of people is demonstrated by their 'works', to be either part of the world or to be born anew from above (Borchert 1996:186; Keener 2003:574). Works appear in a variety of identifications: evil works (3:19-20; 7:7; cf. 2 Jn 11 ; Jn 5:29) or good works, works of truth $(3: 21 ; 8: 39)$; the creative works of the Father and Jesus $(5: 17,20,36)$, and Jesus' ${ }^{\prime}$ works, which often efer to signs $(7: 3,21 ; 9: 3-4 ; 10: 25,32-33,37-38 ; 14: 10-12$; perhaps $15: 24)$ that should have prompted faith $(10: 37-38 ; 14: 11)$. Those who accept the works of Jesus by faith 'will also do the works that I do and, in fact, will do greater works than these' (14:12). 


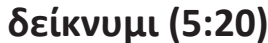

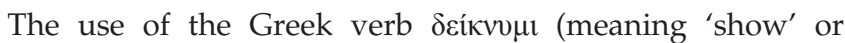
'reveal'), ${ }^{24}$ twice in 5:20, is the author's way of denoting the intimate relation between the Father and Jesus. As the one sent by the Father, Jesus was informed by the Father 'all' he must do and he acted accordingly (17:4). Jesus' actions then became the Father's actions. In fact, the Father was acting in Jesus (Borchert 1996:218). The Johannine readers will also remember the salient analogous statement from the Farewell Discourses where Jesus pointed out to them that in effect believers would 'do even greater things' because of Jesus' returning to the Father (14:12). That proclamation of Jesus should be linked to the expansion of God's working in the world - showing his love through the continuation of God's mission in the world through believers. They should pattern their lives on the life of Jesus, 'the model agent of God' (Borchert 1996:238).

\section{$\kappa \alpha \theta \dot{\omega} \varsigma^{25}$}

The $\kappa \alpha \theta \omega$ 's-particle of comparison ('just as') occurs frequently through the Gospel of John in combining together God-

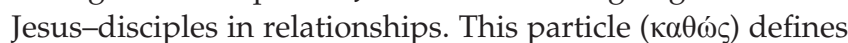
the union:

[B] etween Father and Son (5:30; 8:28; 12:50; 14:31; 17:2; also cf. 5:17-26), between Jesus and his disciples $(13: 15,34 ; 15: 12 ; 17: 14$, 16) and the union involving both relationships $(6: 57 ; 10: 15 ; 14: 20$; 15:9, 10; 17:11, 18, 21, 22; 20:21; cf. 17:23). (Radl 1991:226; Van der Merwe 2017:5)

The author applied this particle on the following essential aspects and daily activities of Jesus and the disciples:

$[D]$ ependence $(5: 19 ; 6: 57 ; 15: 5$; also cf. 12:49; 14:10; 15:15; 17:8), mission (13:20; 17:18; 20:21), knowledge $(10: 14,15)$, love in obedience (13:34f; 15:9; 15:10; 15:12; 17:23; also cf. 5:20; 14:12), unity (14:10; 17:11, 21-23; also cf. 10:30; 14:10f; 14:20; 15:4), glory (15:8; 17:1-5; 22-24) and life (6:57). (Van der Merwe 2001:139)

These activities indicate the en route to obedience. It surely relates to the way people live in everyday life, which comprises conduct in every situation and life together with other people - dependent on Jesus and the Spirit.

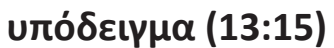

After Jesus washed the feet of his disciples (13:4-12), he tells

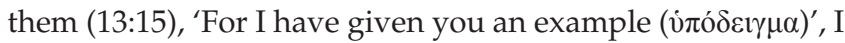
appeal you all to act in a similar way'. Most theological dictionaries translate ínó $\delta \varepsilon \gamma \mu \alpha$ as 'example', 'pattern' or

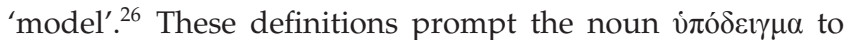
refer to the imitation of both a 'person' or a 'deed' (see Van der Merwe 2001).

24.Arndt et al. (2000:214) define it as to exhibit someth[ing] that can be apprehended by one or more of the senses, point out, show, make known'.

25.The adverbial comparative particle k $\alpha \theta \dot{\omega}$ c occurs 31 times in the Gospel of John $(1: 23 ; 3: 14 ; 5: 23,30 ; 6: 31,57,58 ; 7: 38 ; 8: 28 ; 10: 15 ; 12: 14,50 ; 13: 15,33,34$ $14: 27,31 ; 15: 4,9,10,12 ; 17: 2,11,14,16,18,21,22,23 ; 19: 40 ; 20: 21)$.

26.Arndt et al. (2000:1037) show 'an example of behavior used for purposes of moral instruction, example, model, pattern'. Louw and Nida (1996:I, 591), 'a model of behavior as an example to be imitated or to be avoided - "model, example". Zodhiates (2000:5262), 'An example or pattern to be imitated in action'.
Because of the direct linguistic context (Chapter 13) and larger literary context (Chapters 13-17) of the noun vi ó$\delta \varepsilon \imath \gamma \mu \alpha$ (example), both references (person/deed) consequently can be applied to Jesus: he is (in person) an example and sets (in deeds) an example. Jesus informs his disciples that '[f]or I have set you an example, that you also should do as I have done to you' (13:15). Jesus encourages the disciples to imitate him for he is their master who is par excellence the example of obedience (Van der Merwe 2017:5). This is verified by Jesus in his appeal in the following verse: 'no servant is greater than his master, nor is a messenger greater than the one who sent him' $^{\prime}(13: 16){ }^{27}$

This passage serves as an example (ínó $\delta \varepsilon \gamma \mu \alpha)$ what intense love comprises and should be mimed by the disciples of Jesus (13:1-2,34-35). This activity of Jesus serves to exemplify what intense love is. '[T] he emphasis, lies on the attitude of intense love' (Van der Watt 2017:35). In this act of foot washing, Jesus provides his disciples some ethical guidance teaching them how to treat one another. While Jesus washed their feet, he remains their teacher and lord. In this foot washing, the disciples perceive the meaning of intense love (Van der Watt 2017:35).

Jesus as Lord (13:6) washed the disciples' feet as a symbolic expression to serve one another in love - they also ought to

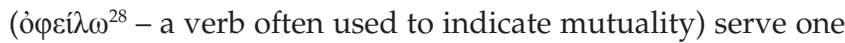
another correspondingly (13:14). Jesus then elaborates on this responsibility, the example he just set in the following verse -

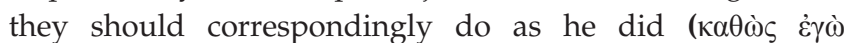
$\dot{\varepsilon} \pi$ oí $\sigma \alpha, 13: 15) .{ }^{29}$ This argument is founded on the superior status of Jesus and expressed in terms of mutuality and mime. 'This is a good example of ancient ethical argumentation, using social expectations to motivate behaviour' (Van der Watt 2017:36).

\section{The rewards of being obedient}

According to the Gospel of John, a life of obedience has certainly some consequences for the believer; the following discussion confirms it:

\section{Experiencing the presence of Jesus and God (Jn 14:21, 23)}

The presence of Jesus and God in the lives of believers is clearly expressed in 14:21, 23 :

Whoever has my commands and obeys them, he is the one who loves me. He who loves me will be loved by my Father, and I too will love him and show myself to him.

27.According to Everett, (2018:258) is discipleship accomplished via servanthood which Jesus illustrated by washing the feet of His disciples - an example of servanthood (13:1-17). He then appropriately explains to them that 'a servant is not greater than his master; nor is he who is sent greater than he who sent him (13:16). From this lesson, the disciples learned that obedience to the works of Jesus starts with humility.

28.Arndt et al. (2000:743) define it as 'to be under obligation to meet certain social or moral expectations, owe'.

29. This statement is based on the common practice of ancient mimesis. Students should mime their teacher or slaves should follow the example(s) set by their lord (Harrison 2013:213-244). 
'If anyone loves me, he will keep my word, and my Father will love him, and we will come to him and make our home

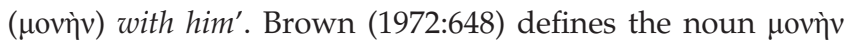
('dwelling place') (30 $^{30}$, 'here it is used for the indwelling of the Father and the Son with the believer'.

The two specific participles in 14:21, "̌ $\chi \omega v$ ('has') and $\tau \eta \rho \tilde{\omega} v$ ('keep' or 'obey'), designate much more than having a list of the commandments of Jesus. Borchert (2002:128) suggests that when the two verbs are interpreted together, this would mean that the commandments, of Jesus for his disciples, are fully amalgamated into the way the disciples live. The commandment of Jesus is certainly not a matter of following some rules. It is rather a way of life. Therefore, Jesus' reference to 'commands' $(14: 21)$ and 'his word/teaching' $(14: 23,24)$ is coupled so closely to loving Jesus. Believing, then, is not only a matter of rational consent. When a person relates to Jesus, it infers obedience, as expressed in 14:15, 'If you love me, you will obey what I command'.

In this pericope, Jesus articulates it so clearly that his presence is real and definite by obeying the command to love him. The rhetorical accent falls not on the admonishment to love, but on the assurance that the one who loves is loved. In 14:2-4, Jesus refers to a transcendent dwelling, which he is going to

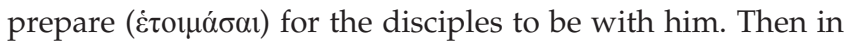
14:21, 23, he defines an immanent residence constituted via obedience by way of love (Brant 2011:215).

\section{Through obedience, believers become friends of Jesus (15:14)}

After commanding his disciples to love one another, Jesus continues saying that 'You are my friends if you do what I command you' (15:14). The emphasis is on 'if you do'. It is synonym to obedience. Goldhill's (1986:82) explanation casts more light on the meaning of 'friendship' in the context that Jesus uses it. He states that in the Greco-Roman context, friendship comprised 'a series of complex obligations, duties and claims' (ref. by Brant 2011:218). This point Jesus already emphasised in verses 14:21, 23. Obedience to his commands explains what it means and comprises to be friends of Jesus.

The concept of being a friend of God is explicitly applied in the Old Testament to Abraham (2 Chr 20:7; Is 41:8; cf. Jas 2:23) and implicitly to Moses (Ex 33:11). Likewise, Jesus can refer to Lazarus as 'our friend Lazarus' (Jn 11:11). The biblical authors, as in the Gospel of John, already (Borchert 2002:149) understood that Jesus was immortal and should not be treated as any other ordinary human. 'Clarity on this issue goes to the very heart of discipleship' (Borchert 2002:150). Therefore, in this context, the reference to friendship should not be labelled as affection (Brant 2011:218). The friendship between Jesus and his disciples is constituted through mutual love. The Gospel of John refers the 'friends' of Jesus to 'those whom he loves' because of their obedience to Jesus' commands (Newman \& Nida 1993:487).

30.See the study by Arndt et al. (2000:658), 'state of remaining in an area, staying tarrying'.

\section{Will be honoured and glorified by God (12:26)}

Jesus promised a double reward for those who serve him (being obedient to him) by following him. He stated in the last two phrases of 12:26 $6^{31}$ that 'where I am, my servant also will be'; ' $[\mathrm{m}] \mathrm{y}$ Father will honor the one who serves me'. In essence, these two expressions are equivalent, expressing the same idea. The disciples will be taken to the presence of Jesus where they will see his glory: 'Father, I desire that they also whom You gave Me may be with Me where I am, that they may behold My glory which You have given $\mathrm{Me}^{\prime}$ (17:24). Jesus expresses these words after he twice referred to the unity (oneness) that should be between himself, the Father and his disciples. The Father, the source of glory and honour 'will take them into the place of honor and glory to share with Christ the same glory and honor that the Father will give the Son' (Kim 2017:170). The disciples will participate in the communion between the Son and the Father in the presence of the Father. 'The honor the Father will bestow on them is to join permanently the eternal and glorious communion of the Father with the Son' (Kim 2017:170).

Both the demand and the reward of the life of following Jesus obediently are distinctly communicated in 12:26. Following Jesus on the journey of death and glory (through death to glory), the faithful servant of Jesus will partake in both suffering and honour, both humiliation and glorification. This is the distinctive aspect of spirituality of being obedient to Jesus that 12:26 communicates in a most distinctive mode. To follow Jesus concerns obedience to his commands and:

$[T]$ o serve him by taking the way of suffering and death into glory, just as Jesus walked the path of death into glory, serving God as the servant, and being honoured by God as the result. (Kim 2017:170)

\section{Will honour and glorify God (17:4)}

Through obedience, God will also be glorified. John describes how Jesus glorified God by doing the things that the Father showed him to do and how believers can glorify God by being obedient.

\section{Evidence from the life of Jesus (Jn 17)}

The glorification of God through obedience is evident from both the life and ministry of Jesus himself (17:4). In this verse, Jesus pronounces to the Father that he has been obedient to what the Father commanded him to do. In the rest of chapter 17 , he elaborates on this:

1. 'I glorified you on earth by finishing the work that you gave me to do' (v. 4).

2. 'I have made your name known to those whom you gave me from the world' (vv. 6, 26).

3. '[T]he words that you gave to me I have given to them' (vv. 8, 14).

4. 'I protected them in your name that you have given me' (v. 12a).

31.'Whoever serves me must follow me, and where $\mathrm{I}$ am, there will my servant be also. Whoever serves me, the Father will honor' (12:26). 
5. 'I guarded them, and not one of them was lost except the one destined to be lost' (v. 12b).

6. 'I have sent them into the world' (v. 18).

7. 'I sanctify myself, so that they also may be sanctified in truth' (v. 19).

8. 'The glory that you have given me I have given them' (v. 22).

Here, in chapter 17, Jesus confesses in the presence of his disciples to the Father his obedience to the Father. He finished the work that the Father gave him to do (17:4). This is not only a prayer to God but also a didactic opportunity used by Jesus to reveal to his disciples paramount secrets, 'his "whence and whither" and his role as God's broker' (Neyrey 2007:280). The Father is glorified in the Son - in his obedience and perfect accomplishment of his work given by the Father. The Father is further glorified in the obedience and fruitfulness of those who follow the Son (Barrett 1978:475) in the example set by him, in obedience to his commands.

\section{Evidence from the lives of Jesus' disciples - 'bearing much fruit' (15:8)}

In 15:8, Jesus said to his disciples that 'This is to my Father's glory, that you bear much fruit, showing yourselves to be my disciples'. The bearing of fruit of the disciples is the result of the redemptive work of the Son (Carson 1991:518) and their obedience to the commands of Jesus. In 15:8, a twofold purpose of fruit bearing is articulated: 'This is to my Father's glory, that you bear much fruit, showing yourselves to be my disciples'. Of interest here is the glorification of the Father.

In the Gospel of John, the verb $\delta$ o $\xi \alpha \dot{\alpha} \omega$ ('glorify') is usually employed in two ways: firstly, it refers to the hour of the glorification of Jesus (his crucifixion and resurrection) and secondly, the result, the glorification of the Father in the Son (7:39; 8:54; 11:4; 12:16, 23, 28; 13:31-32; 14:13; 16:14; 17:1, 4-5; Borchert 2002:145; see Van der Merwe 2002:226-249). Here in $15: 8$, the medium of glorification shifts. The Father is now glorified through the disciples. This reference to glorification must not be understood as denoting that the disciples glorify the Father directly as the consequence of their obedient actions. For the disciples' (branches) abiding in Jesus (the Vine), and consequently be obedient to him in the bearing of much fruit, they glorify the Father. The fruit that stems from their obedient faith-union with Christ and related conduct lie at the centre of how Jesus glorifies the Father (Carson 1991:518).

The prime task of the disciples is to glorify Jesus (cf. 17:10; 21:19) through which the Father is glorified. The bearing of much fruit, hence, not only designates these followers to be true disciples ( $\mu \alpha \theta \eta \tau \alpha i)$ of Jesus but also that God is glorified in their obedient discipleship. Bearing fruit then comprises both the loving of others as God loves them and bearing witness to the world (Witherington 1995:257). Such bearing of much fruit is feasible only by abiding in Jesus (Borchert 2002:145-146). By giving love and keeping Jesus' word, faith comes to fruition (Koester 2008:196).

\section{Some disadvantages of being obedient or not being obedient}

\section{Being obedient in following Jesus}

Unfortunately, sometimes, 'obedience' and 'becoming like Jesus' also come with heavy costs: persecution, rejection and being hated by the world (Jn 15:18-25). In John 15, Jesus said to his disciples, 'If the world hates you, keep in mind that it hated me first' (15:18); 'If they persecuted me, they will persecute you also' (15:20).

\section{Being disobedient in not following Jesus}

In chapter 8, Jesus teaches his disciples that 'I am the light of the world. Whoever follows me will never walk in darkness, but will have the light of life' (8:12); 'I told you that you would die in your sins; if you do not believe that I am the one I claim to be, you will indeed die in your sins' (8:24); '[h]e [the Father] cuts off every branch in me that bears no fruit' (15:2) and '[i]f anyone does not remain in me, he is like a branch that is thrown away and withers; such branches are picked up, thrown into the fire and burned' (15:6).

\section{Conclusion}

According to this study, the Gospel of John is saturated with the concept of obedience and its correlated connotations. Christian obedience is primarily directed to God and secondarily to Jesus. When it is directed to God, the will to follow Jesus' example of love and glorification of God by proclaiming the Gospel are the fundamental principles of obedience. Jesus has indicated that obedience can only be constituted and realised through relationships. His devoted relationship with the Father to commit himself in following the will of the 'one who sent him' forms the other side of his activities of obedience. To live in truth and to be obedient to God, Jesus has set an example to be imitated. The obedience asked from believers arises out of love and is directed towards love (Lee 2002:99-104). This union, originating from Jesus' initiative and sealed by his death on their behalf, is completed by the believers' responsive love and obedience, and is the essence of Christianity (Barrett 1978:470).

To love Jesus is expressed in keeping his commandment. Obedience to this will lead to experiencing the love of the Father (14:21). Through their obedience to Jesus, the disciples will glorify the Father and make the love of him not only known but also experiential. God will become sensible, audible and visible in the world.

\section{Acknowledgements Competing interests}

The author declares that he has no financial or personal relationships that may have inappropriately influenced him in writing this article.

\section{Author's contributions}

D.G.V.D.M is the sole author of this article. 


\section{Ethical considerations}

This article followed all ethical standards for research without direct contact with human or animal subjects.

\section{Funding information}

This research work received no specific grant from any funding agency in the public, commercial or not-for-profit sectors.

\section{Data availability}

Data sharing is not applicable to this article as no new data were created or analysed in this study.

\section{Disclaimer}

The views and opinions expressed in this article are those of the author and do not necessarily reflect the official policy or position of any affiliated agency of the author.

\section{References}

Arndt, W., Danker, F.W. \& Bauer, W., 2000, A Greek-English Lexicon of the New Testamen and other early Christian literature, University of Chicago Press, Chicago, IL.

Barrett, C.K., 1978, The Gospel according to St John: An introduction with commentary and notes on the Greek text, 2nd edn., SPCK, London.

Beasley-Murray, G.R., 1999, John, Word, Incorporated, Dallas, TX.

Bennema, C., 2018, 'Moral transformation through mimesis in the Johannine tradition', Tyndale Bulletin 69(2), 183-203. https://doi.org/10.53751/001c.27689

Berends, B., 2001, 'The obedience of Jesus Christ. A defence of the doctrine of Christ's active obedience', Vox Reformata no edition number, 26-51.

Borchert, G.L., 1996, John 12-21, The New American Commentary, New International Version, Broadman \& Holman, Nashville, TN

Borchert, G.L., 2002, John 12-21, Broadman \& Holman Publishers, Nashville, TN.

Borgen, P., 1968, 'God's agent in the Fourth Gospel', in J. Neusner (ed.), Religions in antiquity, pp. 137-148, Brill, Leiden.

Brant, J.A., 2011, John, Baker Academic, Grand Rapids, MI.

Brodie, T.L., 1993, The gospel according to John. A literary and theological commentary, Oxford University Press, Oxford.

Brown, R.E., 1972, The Gospel according to John, vol. 2, Geoffrey Chapman, London.

Brown, S. \& Skinner, C.W. (eds.), 2017, Johannine ethics: The moral world of the Gospel and Epistles of John, Fortress Press, Minneapolis, MN.

Carson, D.A., 1991, The Gospel according to John, W.B. Eerdmans, Grand Rapids, MI.

D'Angelo, M.R., 1999, 'Intimating deity in the Gospel of John: Theological language and "Father" in "prayers of Jesus"', Semeia 85(1), 59-82.

Das, A.A., 2009, 'Paul and works of obedience in Second Temple Judaism: Romans 4:45 as a "new perspective" case study', The Catholic Biblical Quarterly 71(4), 795-812.

Everett, G.H., 2018, The Gospel of John, United Bible Societies, Stuttgart.

Goldhill, S., 1986, Reading Greek tragedy, Cambridge University Press, Cambridge.

Haenchen, E., 1984, John 1: A commentary on the Gospel of John, Chapters 1-6 (Hermeneia), Fortress, Philadelphia, PA.

Harrison, J.R., 2013, 'The imitation of the "Great Man" in antiquity: Paul's inversion of a cultural icon', in S.E. Porter \& A.W. Pitts (eds.), Christian origins and GrecoRoman culture, pp. 213-254, Brill, Leiden.
Hendriksen, W. \& Kistemaker, S.J., 2001, Exposition of the Gospel according to John, Baker Book House, Grand Rapids, MI.

Josephus, 1987, The works of Josephus, transl. W. Whiston, Hendrickson Publishers, Peabody, MA.

Keener, C.S., 2003, The Gospel of John: A commentary, Baker Academic, Eerdmans, Grand Rapids, MI.

Kelly, J.R., 2013, 'Orders of discourse and the function of obedience in the Hebrew Bible', The Journal of Theological Studies 64(1), 1-24. https://doi.org/10.1093/jts/flt016

Kim, S.S., 2017, The spirituality of following Jesus in John's Gospel: An investigation of Akolouthein and correlated motifs, Pickwick Publications, Eugene, OR.

Koester, C.R., 2008, The word of life: A theology of John's Gospel, Eerdmans, Grand Rapids, MI.

Köstenberger, A.J., 1998, The mission of Jesus and the disciples according to the Fourth Gospel: With implications for the Fourth Gospel's purpose and the mission of the contemporary church, W.B. Eerdmans, Grand Rapids, MI.

Lee, D., 2002, Flesh and glory. Symbol, gender and theology in the Gospel of John, Crossroads Publishing Co., New York, NY.

Lindars, B., 1981, The Gospel of John (The New Century Bible Commentary), W.B. Eerdmans, Grand Rapids, MI.

Louw, J.P. \& Nida, E.A., 1996, Greek-English lexicon of the New Testament: Based on semantic domains, United Bible Societies, New York, NY.

Meyer, P.W., 1996 '“The Father": The presentation of God in the Fourth Gospel', in R.A. Culpepper \& C.C. Black (eds.), Exploring the Gospel of John: In honor of D. Moody Smith, pp. 255-273, Westminster/John Knox, Louisville, KY.

Neyrey, J.H., 2007, The Gospel of John, Cambridge University Press, Cambridge.

Newman, B.M. \& Nida, E.A., 1993, A handbook on the Gospel of John, United Bible Societies, New York, NY.

Peterson, R.A., 2013, 'Union with Christ in the Gospel of John', Presbyterion 39(1), 9-29.

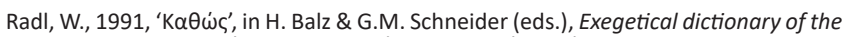
New Testament, vol. 2, p. 226, Eerdmans, Grand Rapids, Ml.

Rensberger, D., 1988, Johannine faith and liberating community, Westminster, Philadelphia, PA, pp. 59-61.

Ridderbos, H., 1997, The Gospel according to John. A theological commentary, Eerdmans, Grand Rapids, Ml.

Stander, A.J.J., 2016, 'Menein as key to a mystical reading of Lohn 15', Unpublished doctoral thesis, University of the Free State.

Taylor, J.E.P., 2017, 'Moses and Old Covenant obedience', Churchman 131(4), 343-359.

Taylor, J.E.P., 2018, 'Paul: A new Moses for a new covenant obedience', Churchman 132(1), 51-69.

Tenney, M.C., 1981, The Gospel of John. Expositor's Bible Commentary, vol. 9, ed. F.E. Gaebelein, Zondervan, Grand Rapids, MI.

Thompson, M.M., 2001, The God of the Gospel of John, Eerdmans, Grand Rapids, MI.

Van der Merwe, D.G., 1995, 'Discipleship in the Fourth Gospel', Unpublished doctoral thesis, University of Pretoria.

Van der Merwe, D.G., 2001, 'Imitatio Christi in the Fourth Gospel', Verbum et Ecclesia 22(1), 131-148. https://doi.org/10.4102/ve.v22i1.628

Van der Merwe, D.G., 2002, 'The Glory-motif in John 17:1-5: An exercise in biblical semantics', Verbum et Ecclesia 23(1), 226-249. https://doi.org/10.4102/ve.v23i1.1250

Van der Merwe, D.G., 2017, 'Conceptualizing holiness in the Gospel of John: The en route to and character of holiness (Part 2)', HTS Teologiese Studies/Theological Studies 73(3), 1-11. https://doi.org/10.4102/hts.v73i3.4610

Van der Watt, J.G., 2017, 'The meaning of Jesus washing the feet of his disciples (John 13)', Neotestamentica 51(1), 25-39. https://doi.org/10.1353/neo.2017.0001

Van der Watt, J.G. \& Zimmermann, R. (eds.), 2012, Rethinking the ethics of John: 'Implicit Ethics' in the Johannine Writings (WUNT 291), Mohr Siebeck, Tübingen.

Westcott B.F., 1908, The Gospel according to St John: The Greek Text with Introduction and Notes, John Murray, London.

Witherington III, B., 1995, John's wisdom. A commentary on the Fourth Gospel, Westminster John Knox Press, Louisville, KY.

Zodhiates, S., 2000, The complete word study dictionary: New Testament, AMG Publishers, Chattanooga, TN. 